\title{
On the application of $\mathrm{Ti} / \mathrm{TiO}_{2} / \mathrm{CuO}$ n-p junction semiconductor: A case study of electrolyte, temperature and potential influence on $\mathrm{CO}_{2}$ reduction
}

\author{
Juliana Ferreira de Brito*, Maria Valnice Boldrin Zanoni \\ Institute of Chemistry-Araraquara, UNESP, Rua Francisco Degni, 55, Bairro Quitandinha, 14800-900 Araraquara, SP, Brazil
}

\section{H I G H L I G H T S}

- Photoelectrochemical $\mathrm{CO}_{2}$ reduction at an n-p Ti/ $/ \mathrm{TiO}_{2} / \mathrm{CuO}$ electrode.

- Formation of methanol, ethanol, and acetone as reduction products.

- Temperature, supporting electrolyte and potential influence in $\mathrm{CO}_{2}$ reduction.

- A charge transfer and reaction scheme are presented to account for the product evolution.

\section{A R T I C L E I N F O}

\section{Article history:}

Available online 3 August 2016

\section{Keywords:}

$\mathrm{CO}_{2}$ reduction

Photoelectrocatalysis

p-n junction

Fuels formation

\begin{abstract}
A B S T R A C T
This work presents the use of photoelectrocatalysis (PEC) aiming at converting $\mathrm{CO}_{2}$ into fuels such as methanol and ethanol. For the $\mathrm{CO}_{2}$ conversion, $\mathrm{Ti} / \mathrm{TiO}_{2} / \mathrm{CuO} n-\mathrm{p}$ junction semiconductor was chosen owing to its heterojunction benefits. The material was constructed using dip-coating technique and was found to present high porosity for both $\mathrm{TiO}_{2}$ and $\mathrm{CuO}$ deposits. Photocurrent vs potential curves showed a relatively good electrode photoactivity for $\mathrm{CO}_{2}$ dissolved in $\mathrm{NaHCO}_{3}$ subjected to UV-Vis commercial irradiation. The $\mathrm{CO}_{2}$ reduction process is found to be deeply affected by the type of electrolyte that, in essence, acts by supporting and generating different quantities of methanol, ethanol and acetone. Methanol is the preponderant fuel generated (91\%) upon the reduction of $\mathrm{CO}_{2}$ by photoelectrocatalysis operating at UV-Vis light and $+0.20 \mathrm{~V}$ as bias potential in $0.1 \mathrm{~mol} \mathrm{~L}^{-1} \mathrm{~K}_{2} \mathrm{SO}_{4}$ and UV-Vis light irradiation. Interestingly though, under $0.1 \mathrm{~mol} \mathrm{~L}^{-1} \mathrm{NaHCO}_{3} \mathrm{pH} 8$ and applied potential of $-0.6 \mathrm{~V}$, we found it feasible to reach $97 \%$ for methanol following $2 \mathrm{~h}$ of reaction. The results primarily unravel an important contribution towards understanding the importance of the electrolyte when it comes to $\mathrm{CO}_{2}$ reduction by photoelectrocatalysis and $\mathrm{Ti} / \mathrm{TiO}_{2} / \mathrm{CuO}$ electrode has clearly proven to be a promising material for the photoelectrochemical $\mathrm{CO}_{2}$ reduction into methanol with high selectivity.
\end{abstract}

(c) 2016 Elsevier B.V. All rights reserved.

\section{Introduction}

The current appalling growing concern for $\mathrm{CO}_{2}$ levels on the planet has widely contributed to fueling a greater demand for methods capable of promoting the reuse of $\mathrm{CO}_{2}$ mainly through its conversion into products with high added value [1]. The literature has reported several methods proposed with this objective in mind among them including biocatalysis [2,3], thermocatalysis [4,5], photocatalysis [6,7], electrocatalysis [8,9] and photoelectrocatalysis $[10,11]$. The methods based on artificial photosynthesis such as photocatalysis have attracted a wider interest as an approach

\footnotetext{
* Corresponding author.

E-mail address: jfbrito@ymail.com.br (J.F.d. Brito).
}

for the conversion of $\mathrm{CO}_{2}$ using solar energy into useful fuels including methane, methanol, carbon monoxide, formic acid and formaldehyde $[1,6,12,13]$. Admittedly though, the method efficiency is found to be limited to easy recombination of charges generated during the process of semiconductor irradiation [14].

Photoelectrocatalysis is a widely known methodology that has been developed capable of effectively combining the photocatalysis technique with bias potential in order to minimize the photogenerated electron-hole pairs recombination, promoting a fast electron transfer to $\mathrm{CO}_{2}$ while at the same time maximizing the yield [11,15-18]. All the results have shown that the electrode material has a significant influence on the $\mathrm{CO}_{2}$ reduction performance and on the selectivity of the products generated. 
One of the main crucial challenges of photoelectrochemistry still lies in the development of materials with visible light activity, high stability and enhanced photoactivity; and as such it bears no difference when the target is $\mathrm{CO}_{2}$ reduction [18]. With this in mind, some research studies have been conducted so as to improve the semiconductor properties where most of them have dealt with the junction of different oxides or metal/oxides types of semiconductors $[16,17,19]$.

The literature reports the use of copper oxides as a good material for $\mathrm{CO}_{2}$ reduction and alcohols formation [15,20-24], nonetheless, copper oxides have been typically found to suffer from photocorrosion [25,26], which compromises their stability when applied towards $\mathrm{CO}_{2}$ reduction by means of photoelectrocatalysis [15]. Aimed at the improvement of copper oxides stability, some researchers have conducted studies coupling these oxides to other materials where they reported a great alteration in terms of the oxides stability $[1,12,27]$.

In general, the coupling of $\mathrm{TiO}_{2}$ to copper oxides may be a good option for improving the stability of the latter and as such has been applied in photocatalysis reactions [1,28-30]. Slamet and collaborators in their works have reported doping the $\mathrm{TiO}_{2}$ Degussa-P25 with copper nitrate, generating different copper species $\left(\mathrm{Cu}^{0}, \mathrm{Cu}^{+}\right.$ and $\mathrm{Cu}^{2+}$ ) which led to their conclusion that $\mathrm{TiO}_{2} / \mathrm{CuO}$ is the better enhancement for the photoreduction of $\mathrm{CO}_{2}$ and methanol formation [28,29]. Qin et al. [1] have studied the $\mathrm{TiO}_{2} / \mathrm{CuO}$ composite for $\mathrm{CO}_{2}$ reduction into methanol as sacrificial reagent and for methyl formate generation. Yuan and other collaborating researchers [30] prepared a copper (I) dye-sensitised $\mathrm{TiO}_{2}$-based system aimed primarily at efficient light harvesting for photoconversion of $\mathrm{CO}_{2}$ into methane $\left(\mathrm{CH}_{4}\right)$. These works have shown that this arrangement can be applied successfully towards improving the $\mathrm{CO}_{2}$ reduction by photocatalysis.

It is noteworthy that the coupling of copper oxides to $\mathrm{TiO}_{2}$ is justified given that $\mathrm{TiO}_{2}$ is the most useful semiconductor applied in photoelectrocatalysis [31,32] owing to its low cost, non-toxicity and high catalytic stability besides the long lifespan of the photogenerated electron/hole pairs [33,34]. However, copper oxide application towards the direct conversion of $\mathrm{CO}_{2}$ by photoelectrocatalysis is found to bear some restrictions. Even so, the coupling of $\mathrm{TiO}_{2} / \mathrm{CuO}$ has yet not been tested in $\mathrm{CO}_{2}$ reduction using photoelectrocatalysis, where the coupling of UV-Vis irradiation and bias potential is seen to be likely more effective a technique compared to photocatalysis.

This paper, at its core, seeks to present the reduction of $\mathrm{CO}_{2}$ dissolved in aqueous medium on $\mathrm{Ti} / \mathrm{TiO}_{2} / \mathrm{CuO}$ electrodes by photoelectrocatalysis aiming at alcohol formation. As $\mathrm{TiO}_{2}$ is said to be a really stable and efficient semiconductor while $\mathrm{Cu}^{2+}$ stands to be a promising candidate when it comes to the reduction of $\mathrm{CO}_{2}$ to alcohol, the coupling of $\mathrm{TiO}_{2}$ and $\mathrm{CuO}$ seeks to investigate a new material for photoelectrocatalytic $\mathrm{CO}_{2}$ reduction with the purpose of raising the degree of stability and understanding the influence it exerts on alcohol formation. The $\mathrm{CO}_{2}$ reduction was analyzed under different supporting electrolyte types and the products formed were quantified using chromatographic techniques.

\section{Experimental part}

\section{1. $p$-n $\mathrm{Ti} / \mathrm{TiO}_{2} / \mathrm{CuO}$ semiconductor}

The $\mathrm{p}-\mathrm{n} \mathrm{Ti} / \mathrm{TiO}_{2} / \mathrm{CuO}$ semiconductor was prepared using titanium isopropoxide and dibasic copper carbonate as precursors of $\mathrm{TiO}_{2}$ and $\mathrm{CuO}$, respectively [35]. Both solutions were prepared with $8.4 \times 10^{-2} \mathrm{~mol} \mathrm{~L}^{-1}$ of metal. The semiconductor was obtained following the deposition of 6 thin films carried out by dip-coating using a solution of $\mathrm{TiO}_{2}: \mathrm{CuO}$ prepared in a proportion of $3: 1(\mathrm{v} /$ $\mathrm{v})$. The semiconductor was calcined after each deposition at $600{ }^{\circ} \mathrm{C}$ with heating rate of $1{ }^{\circ} \mathrm{C} \mathrm{min}{ }^{-1}$ during $90 \mathrm{~min}$. A Ti/TiO semiconductor was prepared for comparison using the same procedure though without the dibasic copper carbonate in the solution. The morphological and structural characterization were carried out by X-ray diffraction (Siemens D5000), FEG-SEM images (Zeiss Supra 35) coupled to EDS analysis. The photocurrent response was evaluated by linear sweep voltammetry in $\mathrm{NaHCO}_{3}$ $0.1 \mathrm{~mol} \mathrm{~L}^{-1}$ at $\mathrm{pH} 8$ with and without $\mathrm{CO}_{2}$ using scan rate of $0.01 \mathrm{~V} \mathrm{~s}^{-1}$ obtained in an Autolab PGSTAT 302.

\subsection{Photoelectrocatalytic $\mathrm{CO}_{2}$ reduction}

The photoelectrochemical experiments were performed in $500 \mathrm{~mL}$ cylindrical two-compartments glass reactor equipped with a cooling system $\left(5^{\circ} \mathrm{C}\right)$. The $\mathrm{Ti} / \mathrm{TiO}_{2} / \mathrm{CuO}$ working electrode $(2.5 \times 2.5 \mathrm{~cm})$ was irradiated with a commercial UV-Vis light obtained from a $125 \mathrm{~W}$ high pressure mercury lamp without the bulb vertically inserted in a central quartz glass tube. A saturated $\mathrm{Ag} / \mathrm{AgCl}$ ( $\mathrm{KCl}$ sat) electrode was used as reference, and the counter electrode was a Pt gauze $(2 \times 1 \mathrm{~cm})$. The $\mathrm{CO}_{2}$ reduction was accomplished by measuring the UV-Vis light and controlled-potential electrolysis carried out in $+0.20 \mathrm{~V}$ and $-0.60 \mathrm{~V}$ using different supporting electrolytes at $\mathrm{pH} 8$ and $0.1 \mathrm{~mol} \mathrm{~L}^{-1}$. The methanol, ethanol and acetone formation were identified and quantified by gas chromatograph instrument coupled to a flame ionization detector (GCFID model 2010 Schimadzu) using the solid-phase microextraction technique (SPME) [15].

\section{Results and discussion}

\subsection{Characterization of $\mathrm{TiO}_{2} / \mathrm{CuO}$ p-n junction semiconductor}

Fig. 1 shows the morphological characteristics of $\mathrm{Ti} / \mathrm{TiO}_{2} / \mathrm{CuO}$ obtained by FEG-SEM. The image shows the Ti substrate completely covered by two different nanoparticles sizes. The smaller particles are $\mathrm{TiO}_{2}$ nanoparticles with high porosity and uniformity with size ranging from 13 to $25 \mathrm{~nm}$. These particles are randomly coated by $\mathrm{CuO}$ particles with size ranging from 100 to $300 \mathrm{~nm}$. The EDS analysis confirmed the $\mathrm{Ti}, \mathrm{Cu}$ and $\mathrm{O}$ presence, as can be observed in Fig. 2a. According to the EDS analysis the weight by

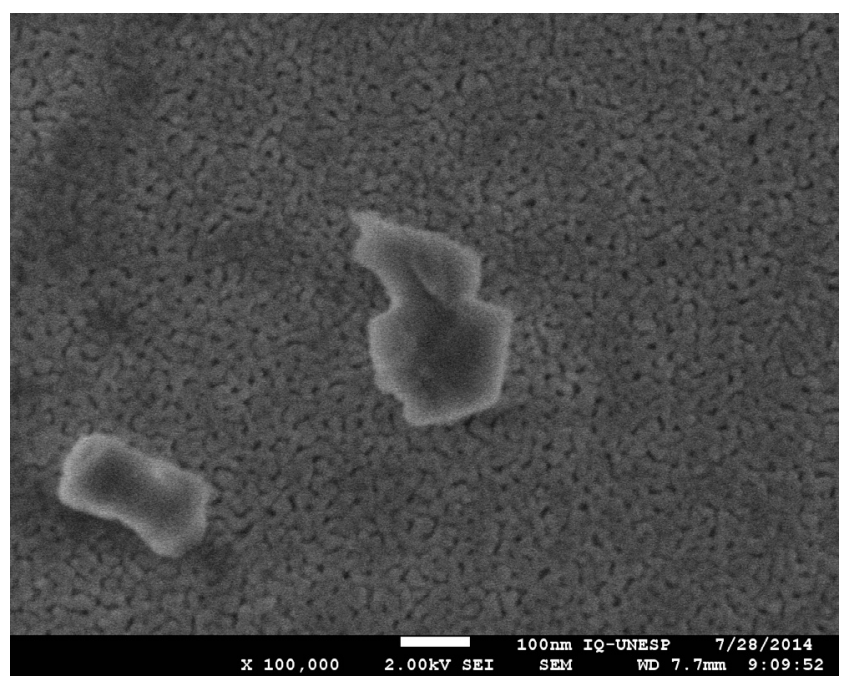

Fig. 1. FEG-SEM image of $\mathrm{Ti} / \mathrm{TiO}_{2}-\mathrm{CuO}$ p-n junction semiconductor prepared with sixty thin layers by dip coating of Ti plate in solution with $3: 1$ of $\mathrm{TiO}_{2}$ and $\mathrm{CuO}$ precursors, respectively, calcined at $600{ }^{\circ} \mathrm{C}$ for $90 \mathrm{~min}$ in each deposition. 


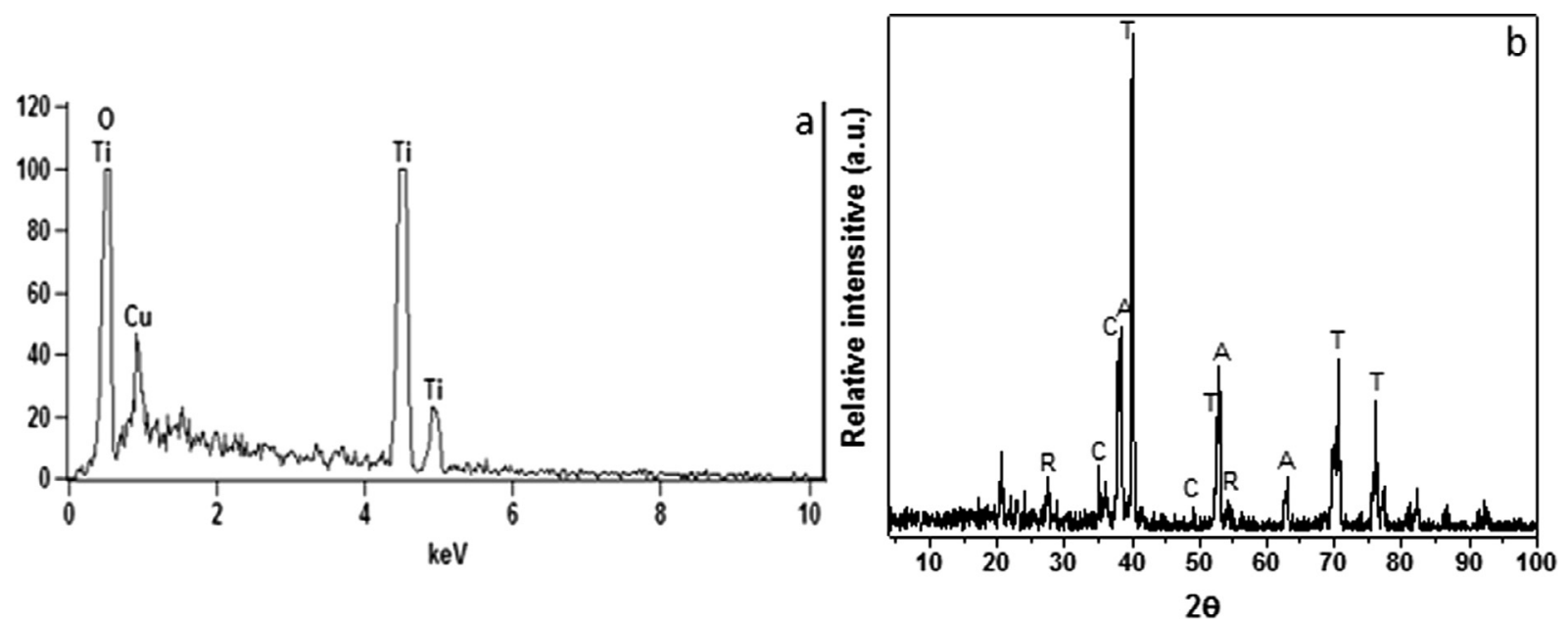

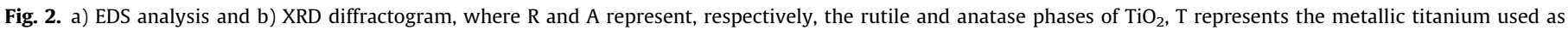
substrate and $\mathrm{C}$ being the $\mathrm{CuO}$ of $\mathrm{Ti} / \mathrm{TiO}_{2}-\mathrm{CuO}$ heterojunction semiconductor.

percentage of which element present in the electrode surface was $39.0 \%$ of oxygen, $55.5 \%$ of titanium and $5.50 \%$ of copper. Therefore, the actual weight ratio of $\mathrm{CuO}$ is $10 \%$ in relation to $\mathrm{TiO}_{2}$. The anatase $\mathrm{TiO}_{2}$ phase formation $(2 \theta=38.2,54.2$ and 63$)$ and the $\mathrm{CuO}$ presence $(2 \theta=35.4,38.7,82.6$ and 86.8$)$ as well as the $\mathrm{Ti}$ $(2 \theta=40,52,70$ and 76$)$ and the rutile $\mathrm{TiO}_{2}$ phase $(2 \theta=27.5$ and 54.4) were confirmed by X-ray diffraction presented in Fig. $2 \mathrm{~b}$.

Fig. 3 illustrates the reflectance spectrum obtained for the Ti/ $\mathrm{TiO}_{2} / \mathrm{CuO}$ semiconductor at the UV-Visible region. The wide optical absorption of the new material is found to be markedly different from the $\mathrm{TiO}_{2}$ semiconductor that presents optical absorption in the ultraviolet region [32] and from the $\mathrm{CuO}$ semiconductor whose optical absorption is seen in the visible region [1]. The coupling of $\mathrm{Ti} / \mathrm{TiO}_{2} / \mathrm{CuO}$ p-n junction can thus be seen to promote better use of radiation coming from a commercial lamp (UV-Vis) for instance or solar irradiation. Furthermore, the inset of Fig. 3 presents the band gap energy for the material obtained by Tauc's graphic [36] using Kubelka-Munk function, according to the Eq. (1) below:

$\alpha=(1-R)^{1 / \gamma} / 2 R$

where $\alpha$ is the material absorptivity and $\mathrm{R}$ being the reflectance. The $\gamma$ was assumed as two (indirect electronic transition allowed)

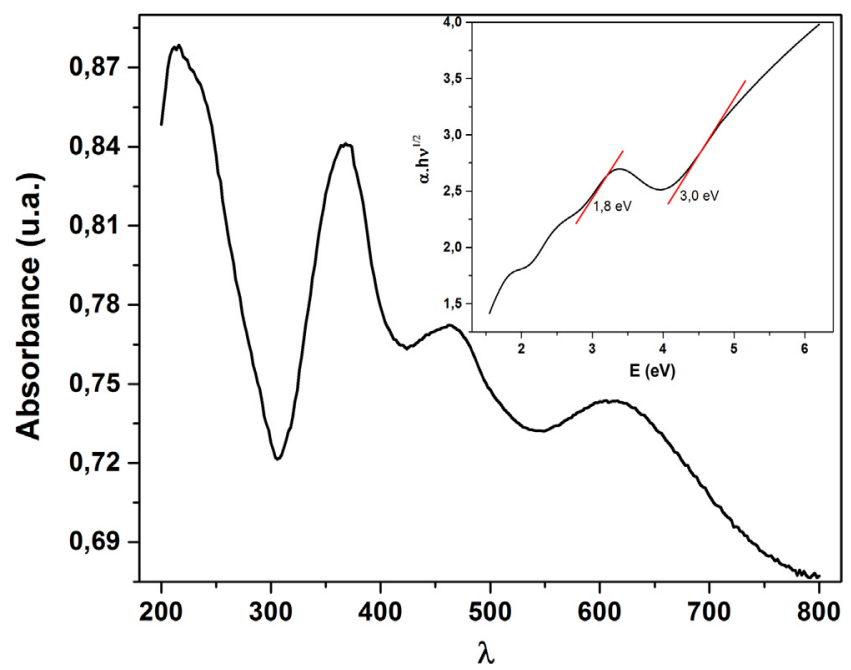

Fig. 3. Diffuse reflectance analysis in UV-vis region with an insert of $\alpha h v^{1 / 2}$ vs $E$ graphic for band gap determination. once this is the electronic transition more suitably indicated for both the $\mathrm{TiO}_{2}$ [37] and $\mathrm{CuO}$ semiconductors [38]. The $\mathrm{Ti} / \mathrm{TiO}{ }_{2} / \mathrm{CuO}$ p-n junction semiconductor presents two values of band gap: $3.0 \mathrm{eV}$ relative to $\mathrm{TiO}_{2}$ contribution [39] and 1.8 relative to $\mathrm{CuO}$ contribution [38]. It is worth pointing out that for the fact that two band gap values have been obtained clearly perhaps substantively reinforces the affirmation that the material exhibits feature of a heterojunction with distinct influences of each semiconductor.

Fig. 4 illustrates the $\mathrm{Ti} / \mathrm{TiO}_{2} / \mathrm{CuO}$ photocurrent response compared to a $\mathrm{Ti} / \mathrm{TiO}_{2}$ semiconductor without copper oxide deposition under dark, irradiation and dissolved $\mathrm{CO}_{2}$. A shifting of $400 \mathrm{mV}$ is observed for $\mathrm{CO}_{2}$ reduction when $\mathrm{TiO}_{2}$ semiconductor is modified with $\mathrm{CuO}$ and exposed to UV-Vis light (Fig. 4a). This behavior is indicative of the role played by $\mathrm{CuO}$ in improving the electron trap when coupled to $\mathrm{TiO}_{2}$.

Fig. $4 \mathrm{~b}$ shows the curves obtained for the $\mathrm{Ti} / \mathrm{TiO}_{2} / \mathrm{CuO}$ p-n junction semiconductor under dark (line I) and under UV-Vis irradiation (line II). The curves can be seen to undergo a steep shift towards a less negative potential when the semiconductor is activated by light, indicating that the electrons and holes pairs $\left(\mathrm{e}^{-} / \mathrm{h}^{+}\right)$ are created inside both $\mathrm{TiO}_{2}$ and $\mathrm{CuO}$, amplifying the charge on the electrode surface. In the presence of $\mathrm{CO}_{2}$, the curve is found to shift to less negative onset potential (from -0.80 to $-0.50 \mathrm{~V} \mathrm{vs} \mathrm{Ag} / \mathrm{AgCl}$ ) in the cathodic region with the same photocurrent value while a high current peak is seen in the anodic region (from 0.03 to $0.1 \mathrm{~mA} \mathrm{~cm}^{-2}$ ). This outcome may be attributed to the $\mathrm{CO}_{2}$ acting as electron scavenger in the $\mathrm{Ti} / \mathrm{TiO}_{2} / \mathrm{CuO} \mathrm{n}$-p junction electrode [1] (curve III, Fig. 4b). The current rises to maximum at potential around $-0.65 \mathrm{~V}$ region, where a defined peak is observed, suggesting that the semiconductor is likely to be a good strategy vis-à-vis the promotion of $\mathrm{CO}_{2}$ reduction.

Taking into account the previous results of diffuse reflectance spectra (Fig. 3) and the studies of Liu et al. [27] and MoralesGuio et al. [40], a schematic relative band position diagram of both $\mathrm{TiO}_{2}$ and $\mathrm{CuO}$ has been presented in Fig. 5. The diagram depicts the potential redox necessary to reduce $\mathrm{CO}_{2}$ to $\mathrm{CH}_{3} \mathrm{OH}(\sim-0.4 \mathrm{~V})$ as well as the potential through which the reduction of $\mathrm{CuO}$ to $\mathrm{Cu}_{2} \mathrm{O}(\sim 0.2 \mathrm{~V})$ occurs both in relation to hydrogen reference electrode [26]. The $\mathrm{TiO}_{2} / \mathrm{CuO}$ configuration presented in the band edges of the two oxides leads to a vector transference of photogenerated electrons from the $\mathrm{TiO}_{2}$ to $\mathrm{CuO}$ particles. During the UV-Vis irradiation of the $\mathrm{TiO}_{2} / \mathrm{CuO}$ surface, a generation of electron hole pairs $\left(\mathrm{e}^{-} / \mathrm{h}^{+}\right)$charges in $\mathrm{TiO}_{2}$ is found to occur. By so doing, the reduction of $\mathrm{CO}_{2}$ on the $\mathrm{TiO}_{2} / \mathrm{CuO}$ surface may be said to take place via two 

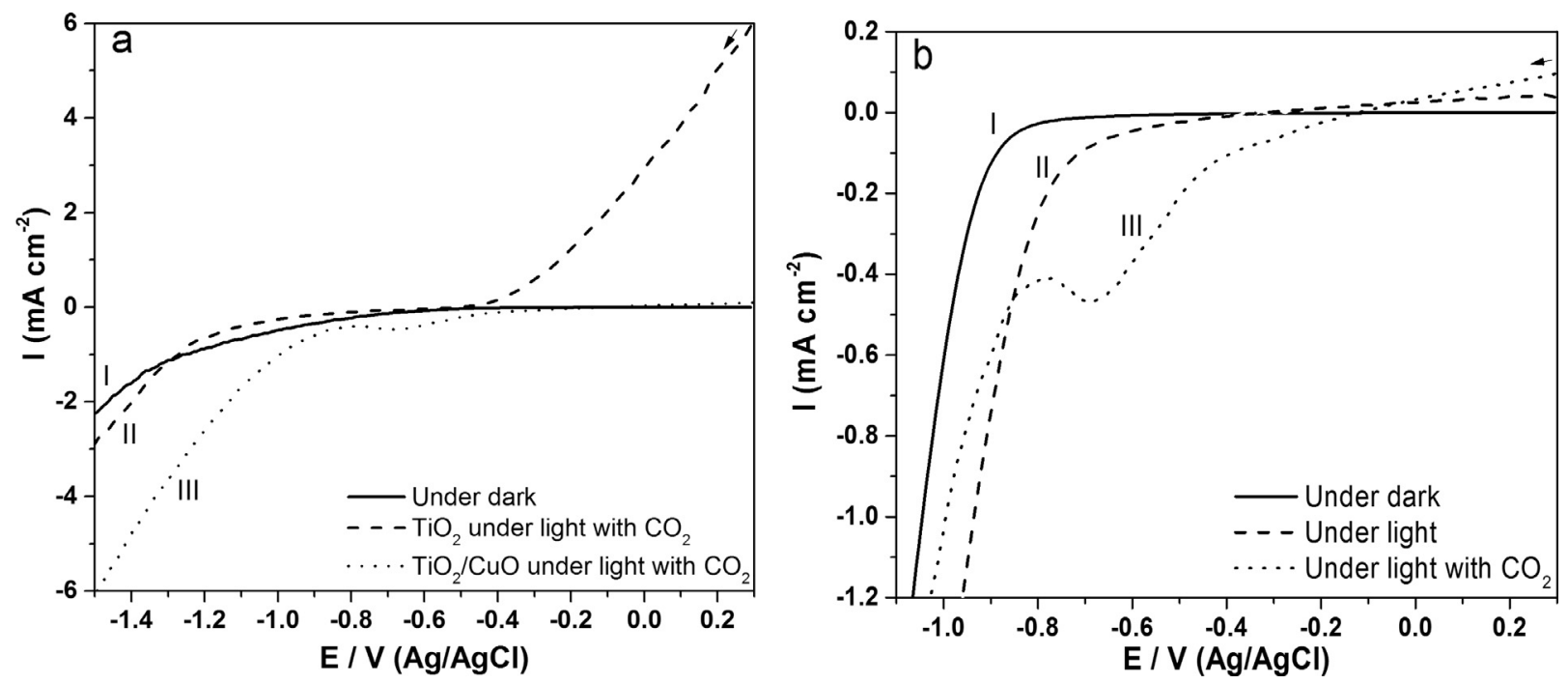

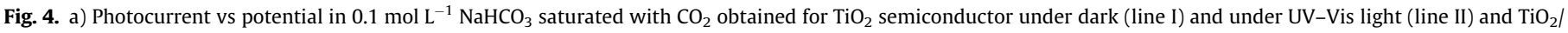

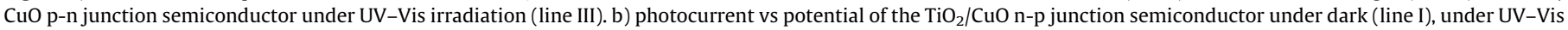
light (line II) and under UV-Vis light with $0.1 \mathrm{~mol} \mathrm{~L}^{-1} \mathrm{NaHCO}_{3}$ saturated with $\mathrm{CO}_{2}$ (line III).

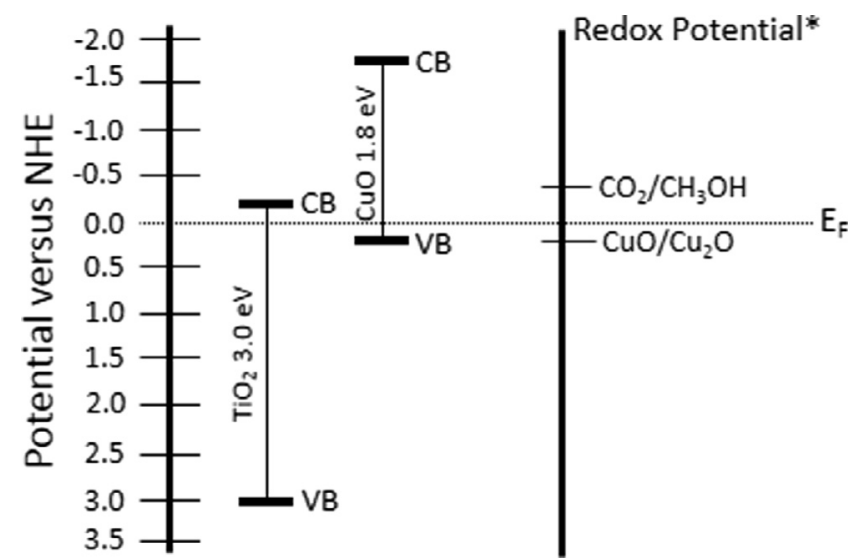

Fig. 5. Energy-band diagram of $\mathrm{TiO}_{2} / \mathrm{CuO}$ p-n junction semiconductor. Semiconductor band edges and redox potential are presented versus $\mathrm{NHE}$ at ${ }^{*} \mathrm{pH} 7$ in aqueous solution, $25^{\circ} \mathrm{C}$ and $1 \mathrm{~atm}(\mathrm{VB}=$ valence band, $\mathrm{CB}=$ conduction band and $\mathrm{E}_{\mathrm{F}}=$ Fermi energy).

modes. At a higher potential such as $-0.6 \mathrm{~V}, \mathrm{CO}_{2}$ reduction is likely to happen directly through the migration of excited $\mathrm{e}^{-}$in the conduction band to the $\mathrm{CO}_{2}$. However, the excited $\mathrm{e}^{-}$in the conduction band of $\mathrm{TiO}_{2}$ could also migrate onto the surface and be trapped by the $\mathrm{CuO}$, leading to the formation of $\mathrm{Cu}^{+}$while undergoing oxidation back to $\mathrm{Cu}^{2+}$, thereby reducing the $\mathrm{CO}_{2}$ to $\mathrm{CO}_{2}^{-}$. This way, the recombination is hindered by both the photoexcited electrons and holes on grounds of their spatial separation. This can contribute towards improving the electrons on the $\mathrm{TiO}_{2} / \mathrm{CuO}$ p-n junction semiconductor surface as verified previously $[29,41]$.

\subsection{Photoelectrocatalytic $\mathrm{CO}_{2}$ reduction}

The photoreduction of $\mathrm{CO}_{2}$ is a multistep process involving adsorption, electron transfers and subsequent reactions [42]. There has been a fundamental consensus on the proposition that the $\mathrm{CO}_{2}^{--}$ radical is the main intermediate, followed in turn by electron addition/protonation reactions [23]. Thus, based on what has been reported in the literature, further experiments were carried out testing PEC performance in order to reduce $\mathrm{CO}_{2}$ in varying potentials, $\mathrm{pH}$ and supporting electrolyte.

\subsubsection{Potential effect}

Fig. 6 shows the products generation when the $\mathrm{Ti} / \mathrm{TiO}_{2} / \mathrm{CuO} \mathrm{n}-\mathrm{p}$ junction semiconductor is acting as photocathode after $2 \mathrm{~h}$ of photoelectrolysis carried out in $0.1 \mathrm{~mol} \mathrm{~L}^{-1} \mathrm{NaHCO}_{3} \mathrm{pH} 8$ saturated with $\mathrm{CO}_{2}$ and applied potential ranging from $-0.60 \mathrm{~V}$ to $+0.20 \mathrm{~V}$. The results indicate that methanol is the preponderant compound formed in both $+0.20 \mathrm{~V}$ and in $-0.60 \mathrm{~V}$. In the case of $\mathrm{CO}_{2}$ reduction at $+0.20 \mathrm{~V}$, the $\mathrm{CO}_{2}$ could be indirectly reduced concomitantly when the $\mathrm{Cu}_{2} \mathrm{O}$ formed is reoxidized to $\mathrm{CuO}$. This behavior essentially corroborates with the results presented in Fig. 4b which presents a shift to more negative onset potential around $-0.60 \mathrm{~V}$, culminating in a higher increase in the current value around $+0.20 \mathrm{~V}$ both in the presence of dissolved $\mathrm{CO}_{2}$.

The semiconductor promotes the generation of the electron $\left(e^{-}\right) /$hole $\left(h^{+}\right)$pair when subjected to irradiation with energy higher than the band gap (Eq. (2)), confirmed by the photocurrent vs potential (Fig. 4). According to Chiang, Amal and Tran [41], CuO has an unfilled $3 d$ shell responsible for its thermodynamically

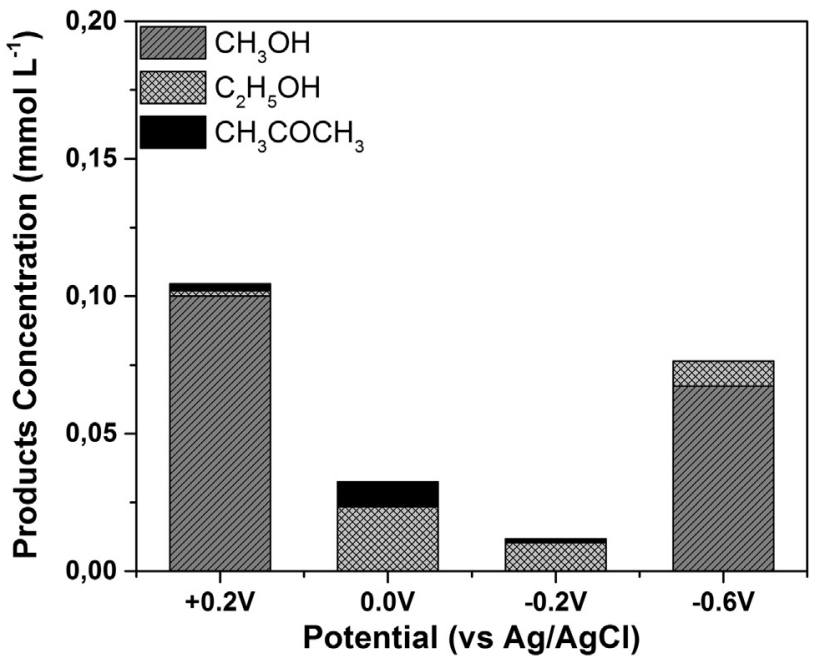

Fig. 6. Evaluation of the products $\mathrm{CH}_{3} \mathrm{OH}$ (gray) $\mathrm{C}_{2} \mathrm{H}_{5} \mathrm{OH}$ (light gray) and $\mathrm{CH}_{3} \mathrm{COCH}_{3}$ (black) formed by photoelectrocatalytic $\mathrm{CO}_{2}$ reduction in $0.10 \mathrm{~mol} \mathrm{~L}^{-1} \mathrm{NaHCO}_{3}$ at $\mathrm{pH} 8$ and $20^{\circ} \mathrm{C}$ applying different potentials and UV-Vis light $(125 \mathrm{~W})$. 
favorable reduction, thus making it an excellent electron trap on the $\mathrm{TiO}_{2}$ surface (Eq. (3)). Tseng and coworkers [43] presented in their manuscript a fluorescence studied in order to prove that electrons generated in the $\mathrm{TiO}_{2}$ are transferred to $\mathrm{CuO}$. This electron needs to be consumed fast, otherwise the $\mathrm{Ti} / \mathrm{TiO}_{2} / \mathrm{CuO}$ surface will be transformed into an accumulator of charges [41] (Eq. (5)). Thus, the $\mathrm{e}^{-}$generated on the $\mathrm{TiO}_{2}$ surface is trapped by the $\mathrm{Cu}^{2+}$ species while the latter is consequently reduced to $\mathrm{Cu}^{+}[26,28]$. Slamet et al. [29] have reported that $\mathrm{Cu}^{+}$are the best adsorption sites for $\mathrm{CO}_{2}$ in a paper they published previously. Hence, the $\mathrm{CO}_{2}$ reduction occurs on $\mathrm{Cu}^{+}$sites where this species undergoes a further reoxidation to $\mathrm{Cu}^{2+}$ (Eq. (6)). The same process is found to occur in the photoelectrocatalytic $\mathrm{CO}_{2}$ reduction under $+0.20 \mathrm{~V}$ owing to the fact that the reduction of $\mathrm{CuO}$ to $\mathrm{Cu}_{2} \mathrm{O}$ is largely favored in this potential $[26,41]$. As a result of this behavior, the reduction of $\mathrm{CO}_{2}$ under $\mathrm{p}-\mathrm{n}$ junction $\mathrm{Ti} / \mathrm{TiO}_{2} / \mathrm{CuO}$ using any of the two potentials and UV-Vis light ensure a better life cycle of the semiconductor, rendering it possible to conduct over 30 experiments at a time with the same electrode without any noticeably significant efficiency loss. The photogenerated hole on the semiconductor surface is responsible for the water oxidation with $\mathrm{OH}$ and $\mathrm{H}^{+}$formation (Eq. (4)) deemed indispensable for the new products formation (Eqs. (7), (8) and (9)). This mechanism ensures a high stability for the $\mathrm{TiO}_{2} / \mathrm{CuO}$ semiconductor and is represented in Fig. 7.

$$
\begin{aligned}
& \mathrm{Ti} / \mathrm{TiO}_{2} / \mathrm{CuO}+h v \rightleftharpoons \mathrm{Ti} / \mathrm{TiO}_{2} / \mathrm{CuO}+\mathrm{e}_{\mathrm{bc}}^{-}+\mathrm{h}_{\mathrm{bv}}^{+} \\
& \mathrm{CuO}+\mathrm{e}_{\mathrm{bc}}^{-} \rightleftharpoons \mathrm{Cu}_{2} \mathrm{O} \\
& \mathrm{H}_{2} \mathrm{O}+\mathrm{h}_{\mathrm{bv}}^{+} \rightleftharpoons \mathrm{H}^{+}+\mathrm{OH}^{\cdot} \\
& \mathrm{Cu}_{2} \mathrm{O}+\mathrm{H}^{+} \rightleftharpoons \mathrm{CuO}+\mathrm{H}^{\cdot} \\
& \mathrm{Cu}_{2} \mathrm{O}+\mathrm{CO}_{2} \rightleftharpoons \mathrm{CuO}+\mathrm{CO}_{2}^{-} \cdot \\
& \mathrm{CO}_{2}+6 \mathrm{H}^{\cdot} \rightleftharpoons \mathrm{CH}_{3} \mathrm{OH}+\mathrm{H}_{2} \mathrm{O} \\
& \mathrm{CH}_{3} \mathrm{OH}+6 \mathrm{H}^{\cdot} \rightleftharpoons \mathrm{C}_{2} \mathrm{H}_{5} \mathrm{OH}+2 \mathrm{H}_{2} \mathrm{O} \\
& \mathrm{CH}_{3} \mathrm{OH}+10 \mathrm{H}^{\cdot} \rightleftharpoons \mathrm{CH}_{3} \mathrm{COCH}_{3}+4 \mathrm{H}_{2} \mathrm{O}
\end{aligned}
$$

The reduction $\mathrm{CO}_{2}$ under $\mathrm{Ti} / \mathrm{TiO}_{2}$ semiconductor was also performed. However, there is no satisfactory performance and none product able to be quantified was detected. In fact, this behavior was expected due the expected performance of the material in the presence or absence of $\mathrm{CO}_{2}$. Ti/TiO 2 semiconductor is a good material to promote oxidation under anodic potential when

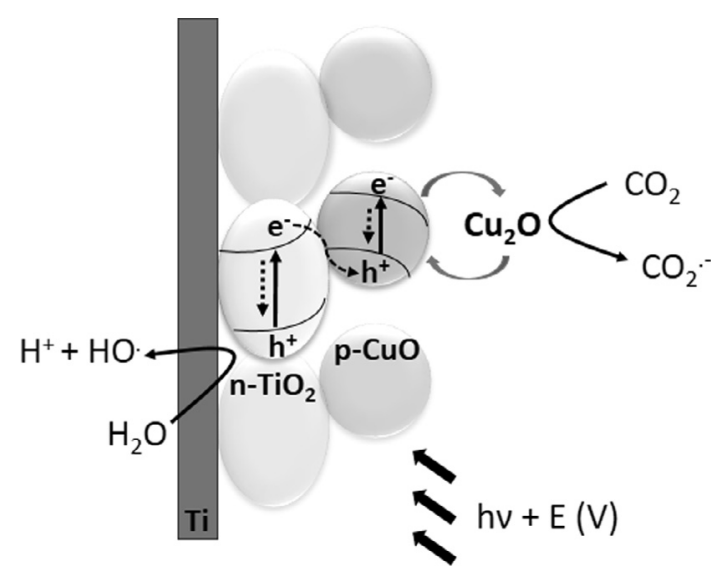

Fig. 7. Charge transfer illustrative mechanism of the p-n junction $\mathrm{Ti}^{2} / \mathrm{TiO}_{2} / \mathrm{CuO}$ semiconductor for the indirect $\mathrm{CO}_{2}$ reduction. irradiated by UV/Vis light. Although, the literature reports a review indicating why should not perform a $\mathrm{CO}_{2}$ reduction under titanium dioxide [7].

\subsubsection{Temperature effect}

Further studies were conducted for $\mathrm{CO}_{2}$ reduction dissolved in $0.10 \mathrm{~mol} \mathrm{~L}^{-1} \mathrm{NaHCO}_{3} \mathrm{pH} 8$ at $\mathrm{Ti} / \mathrm{TiO}_{2} / \mathrm{CuO}$ irradiated by UV-Vis, with applied potential of $-0.60 \mathrm{~V}$ and $+0.20 \mathrm{~V}$, under controlled temperature of 5,20 and $35^{\circ} \mathrm{C}$ using a cooling device. The products quantified after $2 \mathrm{~h}$ of treatment in each case are depicted in Fig. 8.

For both maxima potential applied, photoelectrocatalytic $\mathrm{CO}_{2}$ reduction is obtained at lower temperature such as $5^{\circ} \mathrm{C}$. This can be attributed to the higher solubility of $\mathrm{CO}_{2}$ at low temperature, as reported by Kaneco et al. [44] and Chaplin and Wragg [45]. It is, nonetheless, worth pointing out as shown in Fig. 8a, that at an applied potential of $+0.20 \mathrm{~V}$ one can observe the formation of methanol and ethanol almost in the same concentration $\left(0.10 \mathrm{mmol} \mathrm{L}^{-1}\right)$ while under $-0.60 \mathrm{~V}$ (Fig. 8b) the methanol formed seems to be preponderant reaching three times higher $\left(0.32 \mathrm{mmol} \mathrm{L}^{-1}\right)$. These results clearly indicate a better performance of the photoelectrocatalytic reactor pointing to $97 \%$ of selectivity, which thereby suggests that the method is relatively more selective for methanol formation.

The different oxidative state of the compound formed may be associated with the ease encountered at generating $\mathrm{OH}$. radical during the process $[14,46]$ or at the adsorption effectiveness of $\mathrm{CO}_{2}$ on the electrode surface during photoelectrolysis. It has widely become a known fact that the semiconductor material has the ability to exert a significant influence on the products type formed by $\mathrm{CO}_{2}$ reduction [20]. In addition, the adsorption of $\mathrm{CO}_{2}$ on the electrode surface can take place in different ways on the semiconductor surface when polarized with $+0.20 \mathrm{~V}$ or $-0.60 \mathrm{~V}$ [47].

Under $+0.20 \mathrm{~V}$ potential, the $\mathrm{Ti} / \mathrm{TiO}_{2} / \mathrm{CuO}$ electrode is positively charged, which contributes towards keeping the intermediate generated after the $\mathrm{CO}_{2}$ reduction $\left(\mathrm{CO}_{2}^{-}\right)$adsorbed on its surface, thanks to the opposite charges of the two. Consequently, the subsequent steps of the products formation also occur, possibly, with the intermediate adsorbed on the electrode surface.

On the other hand, under $-0.60 \mathrm{~V}$ potential, the $\mathrm{CO}_{2}^{-}$. intermediate is weakly adsorbed on the electrode surface charged negatively. The similar charges encountered render the adsorption difficult on the $\mathrm{Ti} / \mathrm{TiO}_{2} / \mathrm{CuO}$ surface. The reaction between the intermediate radical and the reactive species present in the medium $\left(\mathrm{H}^{\cdot}\right.$ for example) which are responsible for the products formation [48] occurs in the reaction medium, and not on the electrode surface.

This behavior provides a plausible elucidation concerning the results obtained upon applying photoelectrocatalytic $\mathrm{CO}_{2}$ reduction using UV-Vis light in $0.10 \mathrm{~mol} \mathrm{~L}^{-1} \mathrm{NaHCO}_{3} \mathrm{pH} 8$ at $5{ }^{\circ} \mathrm{C}$ under $-0.60 \mathrm{~V}$ and $+0.20 \mathrm{~V}$ (Fig. 8). The photoelectrocatalysis under $+0.20 \mathrm{~V}$ presented the formation of $0.10 \mathrm{mmol} \mathrm{L}^{-1}$ methanol and $0.09 \mathrm{mmol} \mathrm{L}^{-1}$ ethanol, while under $-0.60 \mathrm{~V}$ the formation was practically selective for methanol forming a concentration of $0.32 \mathrm{mmol} \mathrm{L}^{-1}$.

A mechanism that seeks to explain how the $\mathrm{CO}_{2}$ reduction using photoelectrocatalysis and $\mathrm{Ti} / \mathrm{TiO}_{2} / \mathrm{CuO} \mathrm{p}-\mathrm{n}$ junction semiconductor forms the three different products quantified in this work is presented in Fig. 9. This mechanism was proposed based on some recent works published in the literature $[6,16,49,50]$, where all the authors agree that the products formation occurs via protons and electrons transfers using $\mathrm{Cu}_{2} \mathrm{O}$ as mediator. Methanol is the product identified in relatively greater quantities in this work likewise in other studies reported in the literature [17,19,26,51]. This fact coupled with the time of the reduction studies [16,23] lead us to believe that ethanol and acetone are the products generated through methanol consumption, as demonstrated in the proposed mechanism. 

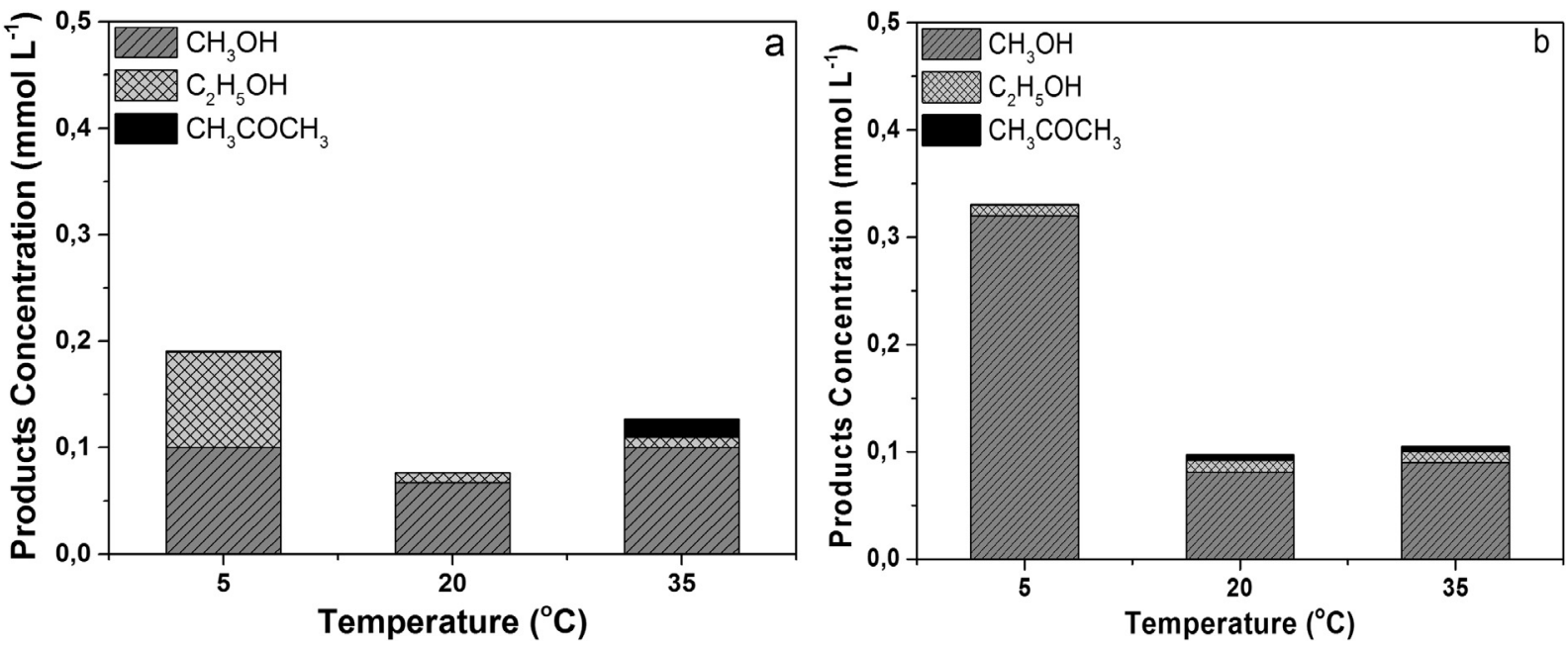

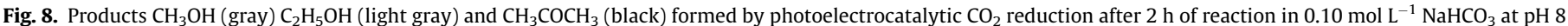
with varying temperatures and UV-Vis light $(125 \mathrm{~W})$ under potential of a) $+0.20 \mathrm{~V}$ and $\mathrm{b})-0.60 \mathrm{~V}$.

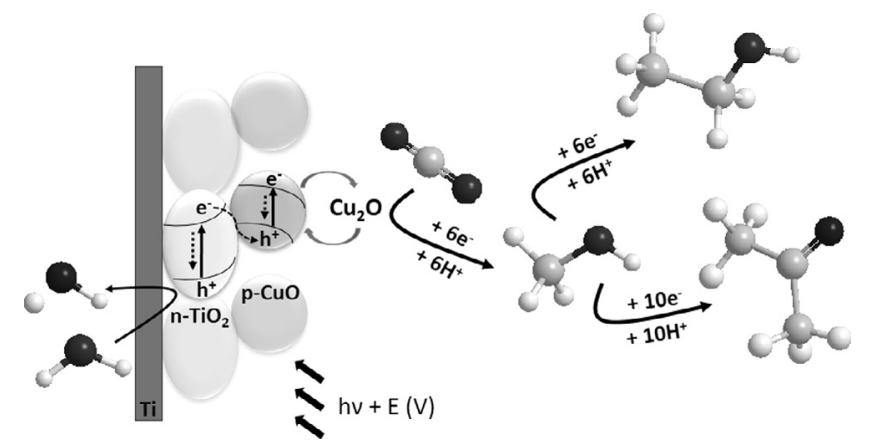

Fig. 9. Mechanism proposed for $\mathrm{CO}_{2}$ reduction by photoelectrocatalysis and methanol, ethanol and acetone formation using $\mathrm{Ti} / \mathrm{TiO}_{2} / \mathrm{CuO} \mathrm{p}-\mathrm{n}$ junction semiconductor.

\subsubsection{Effect of supporting electrolyte}

Besides the effect of temperature on the photoelectrocatalytic reaction, the solubility of $\mathrm{CO}_{2}$ as well as the adsorptive properties on the electrode surface could be altered in different electrolytes [45]. With the aim of investigating this effect, the $\mathrm{CO}_{2}$ conversion in methanol or ethanol was tested using $\mathrm{NaHCO}_{3}, \mathrm{KHCO}_{3}, \mathrm{NaCl}$,
$\mathrm{KCl}, \mathrm{Na}_{2} \mathrm{SO}_{4}$ and $\mathrm{K}_{2} \mathrm{SO}_{4}$ in a concentration of $0.10 \mathrm{~mol} \mathrm{~L}^{-1}, \mathrm{pH} 8$ and under $+0.20 \mathrm{~V}$ and $-0.60 \mathrm{~V}$ bias potential and UV-Vis irradiation incidence in order to evaluate different cations and anions. The products obtained after $2 \mathrm{~h}$ of photoelectrocatalysis are presented in Fig. 10.

Comparing the products obtained under the different supporting electrolytes in both potentials, it is remarkably clear that the quantities and the types of products obtained in each case are different. Interestingly, comparing the results of each supporting electrolyte employed in both potentials applied, we could observe a considerable difference in terms of the products type and concentration, which undoubtedly proves the influence of the potential applied on the semiconductor. According to Sato et al. [52], the use of carbonates and bicarbonate of sodium or potassium has been widely reported in the literature owing to the fact that the supporting electrolyte is not adsorbed on the semiconductor surface besides the maintenance of the species equilibrium seen to occur in the medium. However, by these results we can say that the aforementioned affirmation needs to be linked to the potential applied in the semiconductor. For instance, when the potentials $-0.60 \mathrm{~V}$ and $+0.20 \mathrm{~V}$ were applied in the semiconductor, the best supporting electrolytes obtained for the reduction were $\mathrm{K}_{2} \mathrm{SO}_{4}$
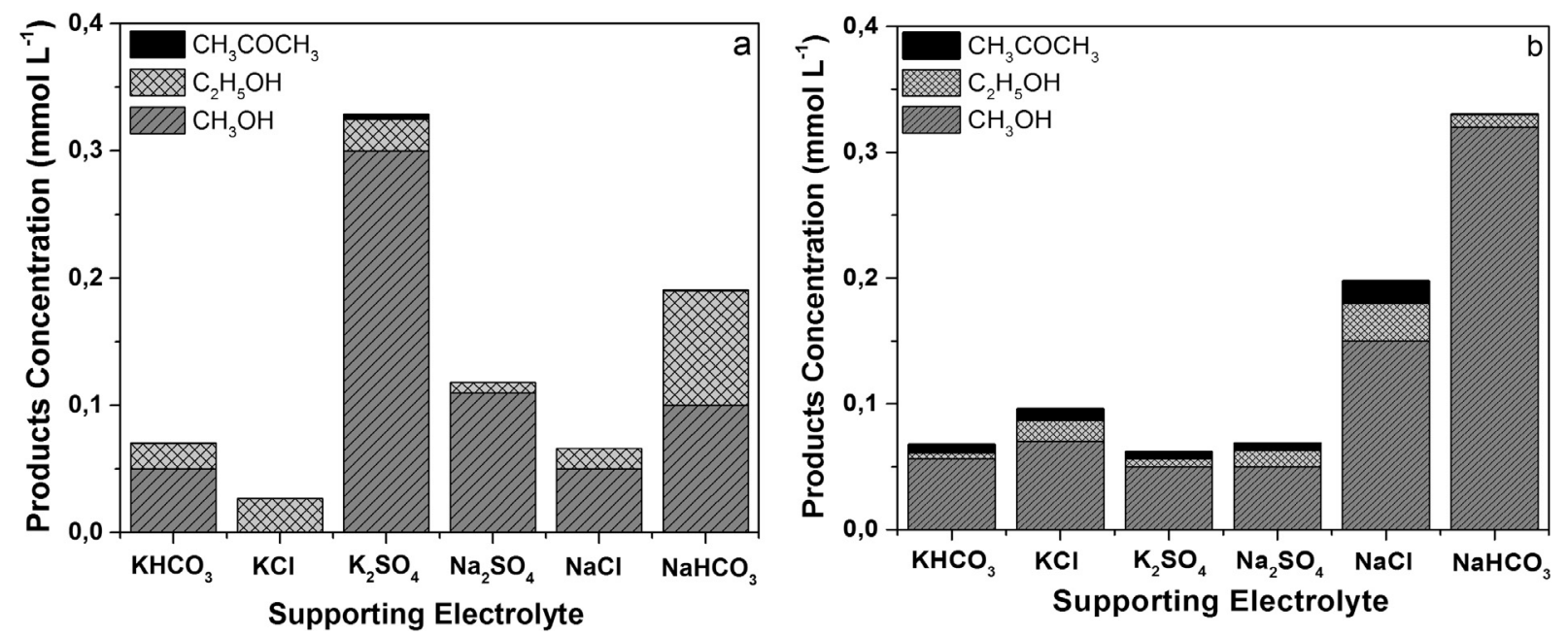

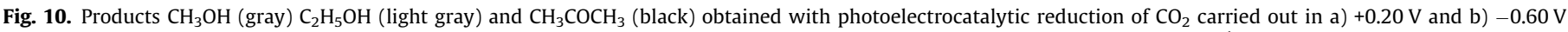
during $2 \mathrm{~h}$ using different supporting electrolytes: $\mathrm{NaHCO}_{3}, \mathrm{KHCO}_{3}, \mathrm{NaCl}, \mathrm{KCl}, \mathrm{Na}_{2} \mathrm{SO}_{4}$ and $\mathrm{K}_{2} \mathrm{SO}_{4}$, all of them at $\mathrm{pH} 8$ and $0.10 \mathrm{~mol} \mathrm{~L}-1$. 
and $\mathrm{NaHCO}_{3}$ respectively, an outcome in line with that reported by Sato et al. [52].

Concerning the reduction occurring under $+0.20 \mathrm{~V}$ (Fig. 10a), despite methanol being the product obtained in higher concentration, ethanol was the only product quantified using $\mathrm{KCl}$ as supporting electrolyte, while ethanol and methanol concentration were practically the same when $\mathrm{NaHCO}_{3}$ was used. A higher products concentration was obtained when $\mathrm{K}_{2} \mathrm{SO}_{4}$ was used, with $91 \%$ of methanol formation, $7 \%$ of ethanol formation and only $2 \%$ of acetone. Analyzing the reaction performed at $-0.60 \mathrm{~V}$ (Fig. 9b), the methanol formation can be seen to be preponderant regardless of the supporting electrolyte employed. However, the methanol concentration is seen to undergo some variation depending on the supporting electrolyte type employed likewise the acetone concentration, though that was not observed when $\mathrm{NaHCO}_{3}$ was employed. Supporting electrolyte with the cations $\mathrm{Na}^{+}$presented higher products formation after $2 \mathrm{~h}$ of reaction compared to the cations $\mathrm{K}^{+}$. In the anions case, the influence found was seen to be less significant. The supporting electrolytes $\mathrm{KHCO}_{3}, \mathrm{~K}_{2} \mathrm{SO}_{4}$ and $\mathrm{Na}_{2}-$ $\mathrm{SO}_{4}$ presented a very similar yield for the products generation under $\mathrm{CO}_{2}$ reduction at $-0.60 \mathrm{~V}$. Furthermore, the higher products formation was obtained using $0.10 \mathrm{~mol} \mathrm{~L}^{-1} \mathrm{NaHCO}_{3}$ at $\mathrm{pH} 8$ after $2 \mathrm{~h}$, exhibiting only methanol and ethanol formation, with $97 \%$ of selectivity for methanol.

\section{Conclusion}

An efficient $\mathrm{Ti} / \mathrm{TiO}_{2} / \mathrm{CuO}$ n-p junction semiconductor was constructed owing to its heterojunction benefits using dip-coating technique. The material obtained presented high porosity for both $\mathrm{TiO}_{2}$ and $\mathrm{CuO}$ deposits, and photoactivity behavior with a typical characteristic of an n-p junction semiconductor. The semiconductor presented a good response for $\mathrm{CO}_{2}$ reduction showing a system with high efficient electron-hole pairs separation, where $\mathrm{CO}_{2}$ acts as preferential electron scavenger. The shifting observed for $\mathrm{CO}_{2}$ reduction when $\mathrm{TiO}_{2}$ semiconductor is modified with $\mathrm{CuO}$ and exposed to UV-Vis light proves that $\mathrm{CuO}$ enhances the $\mathrm{TiO}_{2}$ capacity of $\mathrm{CO}_{2}$ reduction.

The $\mathrm{Ti} / \mathrm{TiO}_{2} / \mathrm{CuO}$ electrode was applied in the photoelectrocatalytic $\mathrm{CO}_{2}$ reduction study and the results show a remarkable behavior when conducted under $0.10 \mathrm{~mol} \mathrm{~L}^{-1} \mathrm{NaHCO}_{3} \mathrm{pH} 8$, UV irradiation at $+0.20 \mathrm{~V}$ and $-0.60 \mathrm{~V}$. A practically selective methanol formation (97\%) was obtained under $0.10 \mathrm{~mol} \mathrm{~L}^{-1} \mathrm{NaHCO}_{3}$ at $\mathrm{pH} 8$ under applied potential of $-0.60 \mathrm{~V}$. A charge transfer and reduction mechanism were presented to illustrate how the photoelectrocatalytic $\mathrm{CO}_{2}$ reduction using a heterojunction semiconductor works. When the $\mathrm{TiO}_{2}$ is subjected to light irradiation, the electrons generated on its surface are found trapped by the $\mathrm{Cu}^{2+}$ species, and the $\mathrm{Cu}^{2+}$ species are consequently reduced to $\mathrm{Cu}^{+}$species. The $\mathrm{CO}_{2}$ reduction occurs on the $\mathrm{Cu}^{+}$sites further reoxidizing the $\mathrm{Cu}^{+}$ species to $\mathrm{Cu}^{2+}$. Primarily as a result of this behavior, a better life cycle of the heterojunction $\mathrm{Ti} / \mathrm{TiO}_{2} / \mathrm{CuO}$ semiconductor was obtained once nearly 30 experiments of $\mathrm{CO}_{2}$ reduction were remarkably accomplished with a single electrode. These results lead us to a plausible conclusion that the electrode stands to be a promising material for photoelectrochemical reduction purposes.

\section{Acknowledgements}

The authors would like to express their deepest gratitude and indebtedness to the Brazilian Research Assistance Agency - FAPESP (2013/25343-8 and 2008/10449-7) for the financial support granted during the course of this research. We are also extremely grateful to Jefferson Brian Newmann - the native English reviewer who painstakingly proof-read and edited this manuscript.

\section{References}

[1] S. Qin, F. Xin, Y. Liu, X. Yin, W. Ma, Photocatalytic reduction of $\mathrm{CO}_{2}$ in methanol to methyl formate over $\mathrm{CuO}-\mathrm{TiO}_{2}$ composite catalysts, J. Colloid Interface Sci. 356 (2011) 257-261, http://dx.doi.org/10.1016/j.jcis.2010.12.034.

[2] A. Alissandratos, H.-K.K. Kim, C.J. Easton, Formate production through biocatalysis, Bioengineered 4 (2013) 348-350, http://dx.doi.org/10.4161/ bioe. 25360 .

[3] H. Choe, J.C. Joo, D.H. Cho, M.H. Kim, S.H. Lee, K.D. Jung, Y.H. Kim, Efficient $\mathrm{CO}_{2}$ reducing activity of NAD-dependent formate dehydrogenase from Thiobacillus sp. KNK65MA for formate production from $\mathrm{CO}_{2}$ gas, PLoS One 9 (2014) 14-16, http://dx.doi.org/10.1371/journal.pone.0103111.

[4] Y. Li, S.H. Chan, Q. Sun, Heterogeneous catalytic conversion of $\mathrm{CO}_{2}$ : a comprehensive theoretical review, Nanoscale 7 (2015) 8663-8683, http://dx. doi.org/10.1039/c5nr00092k.

[5] M.E. Gálvez, P.G. Loutzenhiser, I. Hischier, A. Steinfeld, $\mathrm{CO}_{2}$ splitting via twostep solar thermochemical cycles with $\mathrm{Zn} / \mathrm{ZnO}$ and $\mathrm{FeO} / \mathrm{Fe}_{3} \mathrm{O}_{4}$ redox reactions: thermodynamic analysis, Energy Fuels 22 (2008) 3544-3550.

[6] M. Tahir, N.S. Amin, Advances in visible light responsive titanium oxide-based photocatalysts for $\mathrm{CO}_{2}$ conversion to hydrocarbon fuels, Energy Convers. Manage. 76 (2013) 194-214

[7] S. Navalón, A. Dhakshinamoorthy, M. Álvaro, H. Garcia, Photocatalytic $\mathrm{CO}_{2}$ reduction using non-titanium metal oxides and sulfides, ChemSusChem 6 (2013) 562-577, http://dx.doi.org/10.1002/cssc.201200670.

[8] N. Hollingsworth, S.F.R. Taylor, M.T. Galante, J. Jacquemin, C. Longo, K.B. Holt N.H. de Leeuw, C. Hardacre, $\mathrm{CO}_{2}$ capture and electrochemical conversion using superbasic $\left[\mathrm{P}_{66614}\right][124 \mathrm{Triz}]$, Faraday Discuss. 00 (2015) 1-12, http://dx.doi. org/10.1039/C5FD00091B.

[9] R. Zhang, W. Lv, L. Lei, Role of the oxide layer on Sn electrode in electrochemical reduction of $\mathrm{CO}_{2}$ to formate, Appl. Surf. Sci. 356 (2015) 24 29, http://dx.doi.org/10.1016/j.apsusc.2015.08.006.

[10] C. Ampelli, G. Centi, R. Passalacqua, S. Perathoner, Electrolyte-less design of PEC cells for solar fuels: prospects and open issues in the development of cells and related catalytic electrodes, Catal. Today 259 (2016) 246-258, http://dx. doi.org/10.1016/j.cattod.2015.07.020.

[11] Q. Shen, Z. Chen, X. Huang, M. Liu, G. Zhao, High-yield and selective photoelectrocatalytic reduction of $\mathrm{CO}_{2}$ to formate by metallic copper decorated $\mathrm{Co}_{3} \mathrm{O}_{4}$ nanotube arrays, Environ. Sci. Technol. 49 (2015) 58285835, http://dx.doi.org/10.1021/acs.est.5b00066.

[12] G. Yin, M. Nishikawa, Y. Nosaka, N. Srinivasan, D. Atarashi, E. Sakai, M. Miyauchi, Photocatalytic carbon dioxide reduction by copper oxide nanocluster-grafted niobate nanosheets, ACS Nano 9 (2015) 2111-2119, http://dx.doi.org/10.1021/nn507429e.

[13] P. Akhter, M. Hussain, G. Saracco, N. Russo, New nanostructured silica incorporated with isolated Ti material for the photocatalytic conversion of $\mathrm{CO}_{2}$ to fuels, Nanoscale Res. Lett. 9 (2014) 1-8.

[14] G.G. Bessegato, T.T. Guaraldo, J.F. de Brito, M.F. Brugnera, M.V.B. Zanoni, Achievements and trends in photoelectrocatalysis: from environmental to energy applications, Electrocatalysis 6 (2015) 415-441, http://dx.doi.org/ 10.1007/s12678-015-0259-9.

[15] J.F. Brito, A.A. Silva, A.J. Cavalheiro, M.V.B. Zanoni, Evaluation of the parameters affecting the photoelectrocatalytic reduction of $\mathrm{CO}_{2}$ to $\mathrm{CH}_{3} \mathrm{OH}$ at $\mathrm{Cu} / \mathrm{Cu}_{2} \mathrm{O}$ electrode, Int. J. Electrochem. Sci. 9 (2014) 5961-5973.

[16] T.T. Guaraldo, J.F. de Brito, D. Wood, M.V.B. Zanoni, A new Si/TiO $/ 2$ Pt p-n junction semiconductor to demonstrate photoelectrochemical $\mathrm{CO}_{2}$ conversion, Electrochim. Acta 185 (2015) 117-124, http://dx.doi.org/10.1016/j.electacta. 2015.10.077.

[17] H. Peng, J. Lu, C. Wu, Z. Yang, H. Chen, W. Song, P. Li, H. Yin, Co-doped MoS 2 NPs with matched energy band and low overpotential high efficiently convert $\mathrm{CO}_{2}$ to methanol, Appl. Surf. Sci. 353 (2015) 1003-1012, http://dx.doi.org/10.1016/ j.apsusc.2015.06.178.

[18] P. Li, H. Jing, J. Xu, C. Wu, H. Peng, J. Lu, F. Lu, High-efficiency synergistic conversion of $\mathrm{CO}_{2}$ to methanol using $\mathrm{Fe}_{2} \mathrm{O}_{3}$ nanotubes modified with doublelayer $\mathrm{Cu}_{2} \mathrm{O}$ spheres, Nanoscale 6 (2014) 11380-11386, http://dx.doi.org/ 10.1039/C4NR02902J.

[19] M.R. Hasan, S.B. Abd Hamid, W.J. Basirun, S.H. Meriam Suhaimy, A.N. Che Mat A sol-gel derived, copper-doped, titanium dioxide-reduced graphene oxide nanocomposite electrode for the photoelectrocatalytic reduction of $\mathrm{CO}_{2}$ to methanol and formic acid, RSC Adv. 5 (2015) 77803-77813, http://dx.doi.org/ 10.1039/c5ra12525a.

[20] M. Jitaru, Electrochemical carbon dioxide reduction - fundamental and applied topics (review), J. Univ. Chem. Technol. Metall. 42 (2007) 333-344.

[21] M. Jitaru, D. A. Lowy, M. Toma, B.C. Toma, L. Oniciu, Electrochemical reduction of carbon dioxide on flat metallic cathodes, J. Appl. Electrochem. 27 (1997) 875-889.

[22] G. Ghadimkhani, N.R. de Tacconi, W. Chanmanee, C. Janaky, K. Rajeshwar, Efficient solar photoelectrosynthesis of methanol from carbon dioxide using hybrid $\mathrm{CuO}-\mathrm{Cu}_{2} \mathrm{O}$ semiconductor nanorod arrays, Chem. Commun. (Camb) 49 (2013) 1297-1299, http://dx.doi.org/10.1039/c2cc38068d.

[23] J.F. Brito, A.R. Araujo, K. Rajeshwar, M.V.B. Zanoni, Photoelectrochemical reduction of $\mathrm{CO}_{2}$ on $\mathrm{Cu} / \mathrm{Cu}_{2} \mathrm{O}$ films: product distribution and $\mathrm{pH}$ effects, Chem. Eng. J. 264 (2015) 302-309, http://dx.doi.org/10.1016/j.cej.2014.11.081.

[24] P. Li, J. Xu, H. Jing, C. Wu, H. Peng, J. Lu, H. Yin, Wedged N-doped CuO with more negative conductive band and lower overpotential for high efficiency photoelectric converting $\mathrm{CO}_{2}$ to methanol, Appl. Catal. B Environ. 156-157 (2014) 134-140, http://dx.doi.org/10.1016/j.apcatb.2014.03.011. 
[25] G.K. Mor, O.K. Varghese, R.H.T. Wilke, S. Sharma, K. Shankar, T.J. Latempa, K.S Choi, C.A. Grimes, P-type $\mathrm{Cu}-\mathrm{Ti}-\mathrm{O}$ nanotube arrays and their use in self-biased heterojunction photoelectrochemical diodes for hydrogen generation, Nano Lett. 8 (2008) 1906-1911, http://dx.doi.org/10.1021/nl080572y.

[26] K. Rajeshwar, N.R. De Tacconi, G. Ghadimkhani, W. Chanmanee, C. Janáky, Tailoring copper oxide semiconductor nanorod arrays for photoelectrochemical reduction of carbon dioxide to methanol, ChemPhysChem 14 (2013) 2251-2259, http://dx.doi.org/10.1002/ cphc.201300080.

[27] Y. Liu, H. Zhou, J. Li, H. Chen, D. Li, B. Zhou, W. Cai, Enhanced photoelectrochemical properties of $\mathrm{Cu}_{2} \mathrm{O}$-loaded short $\mathrm{TiO}_{2}$ nanotube array electrode prepared by sonoelectrochemical deposition, Nano-Micro Lett. 2 (2010) 277-284, http://dx.doi.org/10.3786/nml.v2i.

[28] Slamet, H.W. Nasution, E. Purnama, S. Kosela, J. Gunlazuardi, Photocatalytic reduction of $\mathrm{CO}_{2}$ on copper-doped Titania catalysts prepared by improvedimpregnation method, Catal. Commun. 6 (2005) 313-319, http://dx.doi.org/ 10.1016/j.catcom.2005.01.011.

[29] Slamet, H.W. Nasution, E. Purnama, K. Riyani, J. Gunlazuardi, Effect of copper species in a photocatalytic synthesis of methanol from carbon dioxide over copper-doped titania catalysts, World Appl. Sci. J. 6 (2009) 112-122.

[30] Y. Yuan, Z. Yu, J. Zhang, Z. Zou, A copper (I) dye-sensitised $\mathrm{TiO}_{2}$-based system for efficient light harvesting and photoconversion of $\mathrm{CO}_{2}$ into hydrocarbon fuel, Dalton Trans. 41 (2012) 9594-9597, http://dx.doi.org/10.1039/ C2DT30865G.

[31] M.F. Brugnera, K. Rajeshwar, J.C. Cardoso, M.V.B. Zanoni, Bisphenol A removal from wastewater using self-organized $\mathrm{TIO}(2)$ nanotubular array electrodes, Chemosphere 78 (2010) 569-575, http://dx.doi.org/10.1016/j. chemosphere.2009.10.058.

[32] G.G. Bessegato, J.C. Cardoso, M.V.B. Zanoni, Enhanced photoelectrocatalytic degradation of an acid dye with boron-doped $\mathrm{TiO}_{2}$ nanotube anodes, Catal. Today (2015), http://dx.doi.org/10.1016/j.cattod.2014.03.073.

[33] K. Hashimoto, H. Irie, A. Fujishima, $\mathrm{TiO}_{2}$ photocatalysis: a historical overview and future prospects, Jpn. J. Appl. Phys. 44 (2005) 8269-8285, http://dx.doi. org/10.1143/jjap.44.8269. Part 1-Regular Pap. Br. Commun. Rev. Pap..

[34] P. Roy, S. Berger, P. Schmuki, $\mathrm{TiO}_{2}$ nanotubes: synthesis and applications, Angew. Chem. Int. Ed. Engl. 50 (2011) 2904-2939, http://dx.doi.org/10.1002/ anie.201001374.

[35] L. Perazolli, L. Nuñez, M.R.A. da Silva, G.F. Pegler, A.G.C. Costalonga, R. Gimenes, M.M. Kondo, M.A.Z. Bertochi, $\mathrm{TiO}_{2} / \mathrm{CuO}$ films obtained by citrate precursor method for photocatalytic application, Mater. Sci. Appl. 02 (2011) 564-571, http://dx.doi.org/10.4236/msa.2011.26075.

[36] J. Tauc, R. Grigorovici, A. Vancu, Optical properties and electronic structure of amorphous germanium, Phys. Status Solidi 15 (1966) 627-637.

[37] R. López, R. Gómez, Band-gap energy estimation from diffuse reflectance measurements on sol-gel and commercial $\mathrm{TiO}_{2}$ : a comparative study, J. Sol-Gel Sci. Technol. 61 (2012) 1-7, http://dx.doi.org/10.1007/s10971-011-2582-9.

[38] Y.F. Lim, J.J. Choi, T. Hanrath, Facile synthesis of colloidal CuO nanocrystals for light-harvesting applications, J. Nanomater. 2012 (2012), http://dx.doi.org/ $10.1155 / 2012 / 393160$.
[39] A. Ghicov, P. Schmuki, Self-ordering electrochemistry: a review on growth and functionality of $\mathrm{TiO}_{2}$ nanotubes and other self-aligned $\mathrm{MO}(\mathrm{x})$ structures, Chem. Commun. (Camb) (2009) 2791-2808, http://dx.doi.org/10.1039/ b822726h.

[40] C.G. Morales-Guio, S.D. Tilley, H. Vrubel, M. Grätzel, X. Hu, Hydrogen evolution from a copper(I) oxide photocathode coated with an amorphous molybdenum sulphide catalyst, Nat. Commun. 5 (2014) 3059, http://dx.doi.org/10.1038/ ncomms4059.

[41] K. Chiang, R. Amal, T. Tran, Photocatalytic degradation of cyanide using titanium dioxide modified with copper oxide, Adv. Environ. Res. 6 (2002) 471485, http://dx.doi.org/10.1016/S1093-0191(01)00074-0.

[42] L. Liu, Y. Li, Understanding the reaction mechanism of photocatalytic reduction of $\mathrm{CO}_{2}$ with $\mathrm{H}_{2} \mathrm{O}$ on $\mathrm{TiO}_{2}$-based photocatalysts: a review, Aerosol Air Qual. Res. 14 (2014) 453-469, http://dx.doi.org/10.4209/aaqr.2013.06.0186.

[43] I. Tseng, W. Chang, J.C.S. Wu, Photoreduction of $\mathrm{CO}_{2}$ using sol-gel derived titania and titania-supported copper catalysts, Appl. Catal. B Environ. 37 (2002) 37-48.

[44] S. Kaneco, K. Iiba, H. Katsumata, T. Suzuki, K. Ohta, Effect of sodium cation on the electrochemical reduction of $\mathrm{CO}_{2}$ at a copper electrode in methanol, J. Solid State Electrochem. 11 (2007) 490-495, http://dx.doi.org/10.1007/s10008-0060185-0.

[45] R.P.S. Chaplin, A.A. Wragg, Effects of process conditions and electrode material on reaction pathways for carbon dioxide electroreduction with particular reference to formate formation, J. Appl. Electrochem. 33 (2003) 1107-1123.

[46] M.V.B. Zanoni, J.J. Sene, M.A. Anderson, Photoelectrocatalytic degradation of Remazol Brilliant Orange 3R on titanium dioxide thin-film electrodes, J. Photochem. Photobiol. A Chem. 157 (2003) 55-63, http://dx.doi.org/10.1016/ S1010-6030(02)00320-9.

[47] D. Guzmán, M. Isaacs, I. Osorio-Román, M. García, J. Astudillo, M. Ohlbaum, Photoelectrochemical reduction of carbon dioxide on quantum-dot-modified electrodes by electric field directed layer-by-layer assembly methodology, ACS Appl. Mater. Interfaces 7 (2015) 19865-19869, http://dx.doi.org/10.1021/ acsami.5b05722.

[48] M.M. Halmann, M. Steinberg, Greenhouse Gas Carbon Dioxide Mitigation: Science and Technology, sixth ed., Lewis Publishers, Boca Raton, Fla, 1999.

[49] Z. Yang, J. Xu, C. Wu, H. Jing, P. Li, H. Yin, New insight into photoelectric converting $\mathrm{CO}_{2}$ to $\mathrm{CH}_{3} \mathrm{OH}$ on the one-dimensional ribbon CoPc enhanced $\mathrm{Fe}_{2} \mathrm{O}_{3}$ NTs, Appl. Catal. B Environ. 156-157 (2014) 249-256, http://dx.doi.org/ 10.1016/j.apcatb.2014.03.012.

[50] G.K. Ramesha, J.F. Brennecke, P.V. Kamat, The origin of catalytic effect in the reduction of $\mathrm{CO}_{2}$ at nanostructured $\mathrm{TiO}_{2}$ films, ACS Catal. 4 (2014) 3249-3254, http://dx.doi.org/10.1021/cs500730w.

[51] P. Li, J. Zhang, H. Wang, H. Jing, J. Xu, X. Sui, H. Hu, H. Yin, The photoelectric catalytic reduction of $\mathrm{CO}_{2}$ to methanol on $\mathrm{CdSeTe} \mathrm{NSs} / \mathrm{TiO}_{2}$ NTs, Catal. Sci. Technol. 4 (2014) 1070, http://dx.doi.org/10.1039/c3cy00978e.

[52] S. Sato, T. Arai, T. Morikawa, K. Uemura, T.M. Suzuki, H. Tanaka, T. Kajino, Selective $\mathrm{CO}_{2}$ conversion to formate conjugated with $\mathrm{H}_{2} \mathrm{O}$ oxidation utilizing semiconductor/complex hybrid photocatalysts, J. Am. Chem. Soc. 133 (2011) 15240-15243, http://dx.doi.org/10.1021/ja204881d. 